\title{
Enactment and Development of Child-Friendly City Policies in Indonesia
}

\author{
Heru Susetyo ${ }^{1}$, Afdol $^{2}$, Erizka Permatasari ${ }^{3}$, Hani Nur Azizah ${ }^{4}$, Fawzi Muhtadi ${ }^{5}$, Nur Alim \\ Arrazaq $^{6}$ \\ \{hsusetyo@ui.ac.id ${ }^{1}$ \}
}

Faculty of Law, University of Indonesia, 16424, Indonesia ${ }^{1,2,3,4,5,6}$

\begin{abstract}
Indonesia has governed the Child-Friendly City's regulation since 2011 through the Ministry of Women Empowerment and Children Protection Regulation. After being implemented for more than five years, none of Indonesia's cities and regencies have reached the Child-Friendly City's Status. The highest-ranking that was successfully obtained was the 'Main' predicate. However, this 'Utama' predicate is obtained by several cities who don't have specific regulations on Child-Friendly City such as Surabaya and Surakarta, compared to Depok, Yogyakarta, and Magelang who obtained 'Nindya' predicates and already have regional regulation of Child-Friendly City. This tier research will compare the implementation of Child-Friendly City in two eligible cities for children. This research method is empirical and comparative with a qualitative approach. Data obtained through literature studies and field research.
\end{abstract}

Keywords: Enforceability, Development, Policy, City, Child

\section{Introduction}

In a survey conducted by the Economist Intelligence Unit (2019), the world's best places to live in were mostly located in North America (Canada \& USA), Europe, and Australia. These cities are considered worthy as thebest cities because they have low crimerates, minimal crime threats, have a very complete and advanced infrastructure andare child-friendly cities. By contrast, the world's worst cities, still according to Mercer Consulting in 2016 are Baghdad (Iraq), Bangui, Sana'a (Yemen), Port Au Prince (Haiti), and Khartoum (Sudan). What about the cities of Indonesia? None of Indonesia's cities fall into the category of best cities or uncities that are comfortable to livein. However, cities in Indonesia are also not included in the worst category.

In its development, legally, the Awareness of the Government of Indonesia in terms of providing a more livable environment for children began since the ratification of the Convention on the Rights of the Child through presidential decreeNo. 36 of 1990 concerning the Ratification of the Convention on the Rights of the Child. With the ratification of the convention, Indonesia must comply with the provisions of the Convention on the Rights of the Child as described as follows: "... When countries signed the U.N. Convention on the Rights of the Child (CRC), it is expected that legislation at all levels will be brought into compliance with the provisions of the Convention." One of the provisions stipulated in the convention is the implementation of ChildFriendly City. 
In line with this, this paper will answer two important problem formulations: (1) How is child-friendly city in Depok, Surakarta, Magelang, Yogyakarta, and Surabaya?; and (2) What are the alternative child-friendly city policies thatcan be applied by the Depok City Government?

\section{Literature Review}

Child-Friendly City is a district / city that has a development system based on children's rights through the integration of commitments and resources of the government, community and business world thatg planned thoroughly and sustainably in policies, programs and activities to ensure the fulfillment of children's rights. The KLA consists of 6 institutional indicators and 25 indicators of substance grouped into 5 child klaster rights clustersnamely civilrights and freedoms; alternative family and parenting environments; basic health and well-being; education; utilization of leisure time and cultural activities; and special protection.

According to UNICEF, Child-Friendly Cities must guarantee every child's right to (1)participate in influencing policies towards their cities; (2) to express their opinion on the city they want; (3) participate in family, community and social life; (4) obtain basic services such as healthcare, education and housing services; (5) be able to drink clean water and have access to proper sanitation; (6) Protected from exploitation, violence and persecution; (7) Free to walk safely on the streets; (8) meet and play withn-friend theme; (9) have green spaces for growth and animals; (10) living in a pollution-free environment; (11) may participate in cultural and social activities; (12) become a citizen who has equal rights and opportunities in nature toaccess everyministry, regardless of ethnic origin, religion, income, gender and disability.

\section{Method}

The research method used in producing this paper is the normative legal research method. In normative law research, researchers only use library materials or secondary data consisting of primary legal materials, secondary legal materials, and tertiary legal materials that regulate or discuss about Child-Friendly Cities both national and local regulations governing ChildFriendly Cities. Technical data analysis used in this researchis technical qualitative data analysis.

\section{Results and Discussion}

\subsection{Child-Friendly City Arrangements in Indonesia}

In general, Indonesia has ratified the Convention on the Rights of the Child through the Decree of the Republic of Indonesia Number 36 of 1990 concerning Hak-Hak the Ratification of the Convention on The Rights of The Child. As a follow-up to the ratification, the government through the Ministry of Women Empowerment and Child Protection has issued legal instruments for implementing child-friendly city policies as follows: 
1. Regulation of the Minister of Women Empowerment and Child Protection of the Republic of Indonesia Number 11 of 2011 concerning Child-Friendly Regency/City Development Policy.

2. Regulation of the Minister of Women Empowerment and Child Protection of the Republic of Indonesia Number 12-year 2011 concerning Indicators of Child-Friendly Districts/Cities.

3. Regulation of the Minister of Women Empowerment and Child Protection of the Republic of Indonesia Number 13-year 2011 concerning Guidelines for Development of Child-Friendly Districts/Cities.

4. Regulation of the Minister ofState for Women's Empowerment and Child Protection of the Republic of Indonesia Number 14 of 2011 concerning Guidelines for Evaluation of Child-Friendly Districts/Cities.

Above regulations are further set forth in the form of regulationsat the regional level, can be in the form of RegionalRegulations or Mayors / Regent Regulations, either united in child protection regulations or made in a separate regulation.

\subsection{Implementation of Child-Friendly Cities in Depok, Surakarta, Magelang, Yogyakarta, and Surabaya}

Before explaining more about the implementation of Child-Friendly Cities in each region, we have summarized the achievements achieved by each region in the Child-Friendly City award as described in Table 1.

Table 1. Child-Friendly City Awards obtained by each City in 2017-2019

\begin{tabular}{llllll}
\hline Years & Depok & Magelang & Yogyakarta & Surabaya & Surakarta \\
\hline $\mathbf{2 0 1 9}$ & Nindya & Nindya & Nindya & Main & Main \\
$\mathbf{2 0 1 8}$ & Nindya & Nindya & Nindya & Main & Main \\
$\mathbf{2 0 1 7}$ & Nindya & Nindya & Madya & Main & Main \\
\hline
\end{tabular}

In this case, Tabel 1 shows that the author will compare the implementation of ChildFriendly City that received the Main award (Surakarta and Surabaya) with the Child-Friendly City with the Nindya (Depok, Magelang, and Yogyakarta) awards.

\subsubsection{Child-friendly city law instruments}

Table 2 shows the child-friendly city regulation in each region

Table 2. Child-Friendly City Regulation in each region

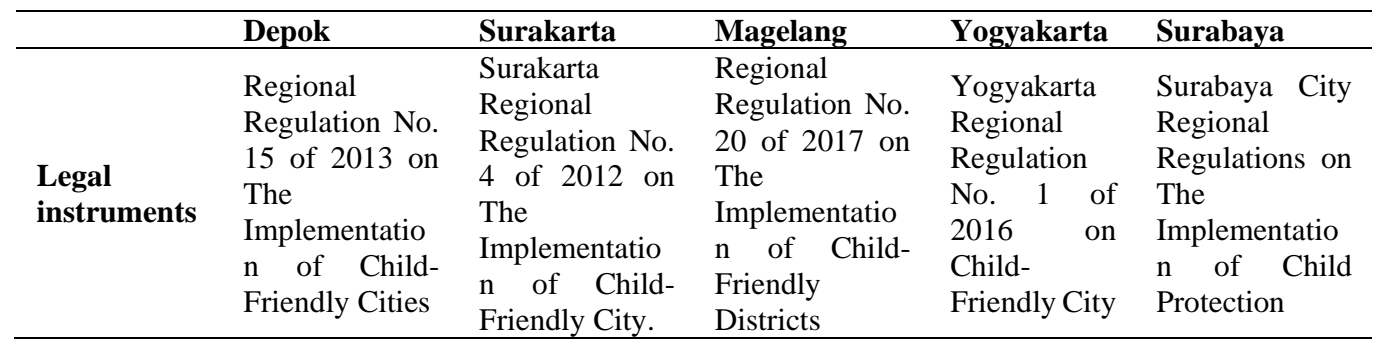


Based on Table 2, We discovered an interesting fact: even Surakarta and Surabaya are awarded as eligible cities for children with Utama-tier, they don't have any specific regional regulation for Child-Friendly Cities. Child-Friendly City Arrangements in Surakarta are still regulated and the Mayor's Regulation. This is different from the city with nindya category that already has a special regional regulation on Child-Friendly City.

\subsubsection{Civil rights and freedoms}

Table 3 shows Implementation of Children Civil Rights and Freedom's fulfilment.

Table 3. Implementation of Children Civil Rights and Freedom's fulfilment

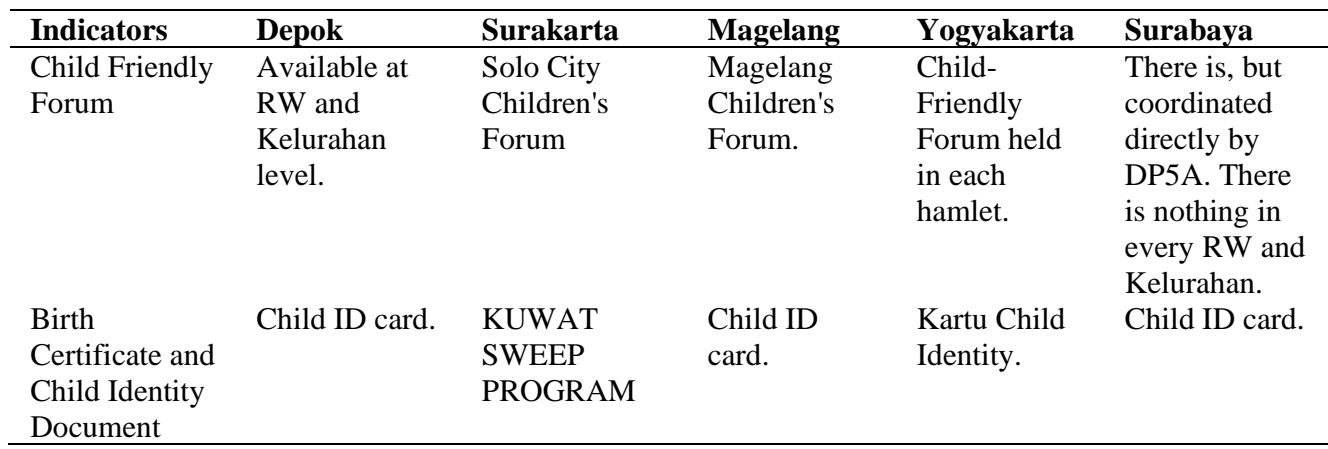

Based on Table 3, in Depok, in addition to being involved in Child-Friendly Forum, children are also involved in the Deliberation of Village Development Plan (Musrengbangkel) and Deliberation of District Development Plan (Musrengbang). While Surakarta has an innovation to make SAPU KUWAT (One Package of Population Affairs Fulfilled), a service to make birth certificates easily, free and direct.

\subsubsection{Family environment and alternative parenting}

Table 4 shows implementation of family environment and alternative parenting's rights fulfilment.

Table 4. Implementation of family environment and alternative parenting's rights fulfilment

\begin{tabular}{|c|c|c|c|c|c|}
\hline Indicators & Depok & Surakarta & Magelang & Yogyakarta & Surabaya \\
\hline $\begin{array}{l}\text { Child-Friendly } \\
\text { Village / RW }\end{array}$ & $\begin{array}{l}\text { Initiator of } \\
\text { Child-Friendly } \\
\text { RW. } \\
\text { Pilot RW: RW } \\
13 \text { Cisalak } \\
\text { Village. It has } \\
\text { a dedicated } \\
\text { RW Child- } \\
\text { Friendly } \\
\text { website. }\end{array}$ & $\begin{array}{l}\text { Child Friendly } \\
\text { Family, Child } \\
\text { Friendly RT, } \\
\text { Child Friendly } \\
\text { RW. }\end{array}$ & $\begin{array}{l}\text { Child-friendly } \\
\text { villages and } \\
\text { Child-Friendly } \\
\text { Subdistricts. }\end{array}$ & $\begin{array}{l}192 \text { Child- } \\
\text { Friendly } \\
\text { Villages, but } \\
\text { only a few } \\
\text { villages that } \\
\text { still } \\
\text { implement the } \\
\text { Child-Friendly } \\
\text { environment. }\end{array}$ & $\begin{array}{l}\text { Don't have } \\
\text { Child- } \\
\text { Friendly } \\
\text { RT yet }\end{array}$ \\
\hline
\end{tabular}


Based on Table 4, in Magelang, Child-Friendly Villages and Child-Friendly Sub-Districts are not yet owned by every village and sub-district. It is recorded that only 11 out of 21 subdistricts are designated as Child-Friendly Sub-Districts and 72 out of 372 villages are designated as Child-Friendly Villages. While di Yogyakarta, although there are 192 Child-Friendly Villages, only a few villages are still actively implementing child-friendly programs.

\subsubsection{Basic health and wellbeing}

Table 5 shows the Implementation of children basic health and wellbeing rights fulfilment.

Table 5. Implementation of children basic health and wellbeing rights fulfilment

\begin{tabular}{|c|c|c|c|c|c|}
\hline Indicators & Depok & Surakarta & Magelang & Yogyakarta & $\begin{array}{l}\text { Surabay } \\
\text { a }\end{array}$ \\
\hline $\begin{array}{l}\text { Complete } \\
\text { Basic } \\
\text { Immunization }\end{array}$ & Available & Available & $\begin{array}{l}\text { Available } \\
\text { with } \\
\text { achievement } \\
\text { of } 24.8 \% \text { from } \\
\text { target of } \\
23.8 \%\end{array}$ & Available & Available \\
\hline $\begin{array}{l}\text { Non-Smoking } \\
\text { Areas }\end{array}$ & Available & Available & Available & Available & Available \\
\hline
\end{tabular}

\subsubsection{Utilization of leisure and cultural activities} fulfilment.

Table 6 shows Implementation of children utilization of leisure and cultural activities rights

Table 6. Implementation of children utilization of leisure and cultural activities rights fulfilment

\begin{tabular}{|c|c|c|c|c|c|}
\hline Indicators & Depok & Surakarta & Magelang & $\begin{array}{l}\text { Yogyakart } \\
\text { a }\end{array}$ & Surabaya \\
\hline $\begin{array}{l}\text { Compulsory } \\
\text { Study } 12 \\
\text { years }\end{array}$ & $\begin{array}{l}\text { It's there and } \\
\text { it's free. }\end{array}$ & $\begin{array}{l}\text { It's there and } \\
\text { it's free. }\end{array}$ & $\begin{array}{l}\text { It's there } \\
\text { and it's free. }\end{array}$ & $\begin{array}{l}\text { It's there } \\
\text { and it's free. }\end{array}$ & $\begin{array}{l}\text { It's there and } \\
\text { it's free. }\end{array}$ \\
\hline $\begin{array}{l}\text { Early } \\
\text { Childhood } \\
\text { Education }\end{array}$ & $\begin{array}{l}\text { Only } 3 \text { State } \\
\text { Early } \\
\text { Childhood } \\
\text { Education of } \\
1292 \text { Early } \\
\text { Childhood } \\
\text { Education }\end{array}$ & $\begin{array}{l}14 \text { State Early } \\
\text { Childhood } \\
\text { Education of } \\
523 \text { Early } \\
\text { Childhood } \\
\text { Education }\end{array}$ & $\begin{array}{l}1 \text { State } \\
\text { Early } \\
\text { Childhood } \\
\text { Education } \\
\text { of } 147 \text { Early } \\
\text { Childhood } \\
\text { Education }\end{array}$ & $\begin{array}{l}20 \text { State } \\
\text { Early } \\
\text { Childhood } \\
\text { Education } \\
\text { of } 708 \\
\text { Early } \\
\text { Childhood } \\
\text { Education } \\
\end{array}$ & $\begin{array}{l}2 \text { State Early } \\
\text { Childhood } \\
\text { Education of } \\
2809 \text { Early } \\
\text { Childhood } \\
\text { Education }\end{array}$ \\
\hline
\end{tabular}

Based on Table 6, although depok city has provided mandatory learning facilities for 12 years, but the educational facilities in depok city are not adequate. There are only 26 public junior high schools in Depok. The number is considered to have not met the needs of children to continue their education to a higher level when compared to the number of public elementary schools in Depok which amounted to 238 elementary schools. 


\subsubsection{Special protection}

Table 7 shows that to provide the Government of Surabaya provides facilities Kampung Anak Negeri and Child Friendly Shelter to accommodate children facing certain cases. The same service, which distinguishes child-friendly shelters, is intended for children's victims of sexual abuse, children facing thelaw, and other cases that are quite severe. While Kampung Anak Negeri is intended as a permanent residence for children with cases that are not as severe as children accommodated in Child-Friendly Shelter. The child who lives there is covered by the government and gets counseling facilities online. In Depok and Surakarta, until now, there is no children's rehabilitation center. As for child labor, Depok still facesdifficulties in handling it because of the difficulty of identifying childrenwho come from Depok with other child laborers who are speeders.

Table 7. Implementation of children speial protection rights fulfilment

\begin{tabular}{|c|c|c|c|c|c|}
\hline $\begin{array}{l}\text { Special } \\
\text { Protection }\end{array}$ & Depok & Surakarta & Magelang & Yogyakarta & Surabaya \\
\hline $\begin{array}{l}\text { Handling of } \\
\text { children } \\
\text { exempt from } \\
\text { forms worst } \\
\text { job kid }\end{array}$ & $\begin{array}{l}\text { There is no } \\
\text { child-only } \\
\text { rehabilitation } \\
\text { house yet. }\end{array}$ & $\begin{array}{l}\text { Integrated } \\
\text { Service } \\
\text { Technical } \\
\text { Implementatio } \\
\text { n Unit for } \\
\text { women and } \\
\text { children (UPT. } \\
\text { PTPAS) }\end{array}$ & $\begin{array}{l}\text { BRSAMPK } \\
\text { (Center for } \\
\text { Social } \\
\text { Rehabilitation } \\
\text { of Children In } \\
\text { Need of } \\
\text { Special } \\
\text { Protection) } \\
\text { "Antasena" }\end{array}$ & $\begin{array}{l}\text { Center for } \\
\text { Social } \\
\text { Rehabilitation } \\
\text { of Bina Karya } \\
\text { Dan Laras } \\
\text { (BRSBKL) }\end{array}$ & $\begin{array}{l}\text { Kampung } \\
\text { Anak Negeri } \\
\text { and Child- } \\
\text { Friendly } \\
\text { Shelter }\end{array}$ \\
\hline $\begin{array}{l}\text { Handling of } \\
\text { children } \\
\text { facing the } \\
\text { law }(\mathrm{ABH})\end{array}$ & $\begin{array}{l}\text { There is no } \\
\text { child-only } \\
\text { rehabilitation } \\
\text { house yet. }\end{array}$ & $\begin{array}{l}\text { Integrated } \\
\text { Service } \\
\text { Technical } \\
\text { Implementatio } \\
\text { n Unit for } \\
\text { women and } \\
\text { children (UPT. } \\
\text { PTPAS) }\end{array}$ & $\begin{array}{l}\text { BRSAMPK } \\
\text { (Center for } \\
\text { Social } \\
\text { Rehabilitation } \\
\text { of Children In } \\
\text { Need of } \\
\text { Special } \\
\text { Protection) } \\
\text { "Antasena" }\end{array}$ & $\begin{array}{l}\text { Center for } \\
\text { Social } \\
\text { Rehabilitation } \\
\text { of Bina Karya } \\
\text { Dan Laras } \\
\text { (BRSBKL) }\end{array}$ & $\begin{array}{l}\text { Kampung } \\
\text { Anak Negeri } \\
\text { and Shelter } \\
\text { Friendly } \\
\text { Anak }\end{array}$ \\
\hline
\end{tabular}

\subsection{Alternative Child-Friendly City Policy in Depok}

Here are some alternative child-friendly city policies that can be applied in Depok:

1. Improving the quality and quality of monitoring and evaluation of the implementation of Child-Friendly City in Depok City.

2. Working with NGOs and/or Companies in the framework of implementing corporate social responsibility in terms of providing children's rights, such as the construction of rehabilitation houses for children as victims or children facing laws requiring restoration or construction of Green Open Spaces. 


\section{Conclusion}

In general, Depok, Magelang, Yogyakarta, Surakarta, and Surabaya already have legal instruments in the implementation of Child-Friendly City and its supporting facilities, both in terms of infrastructure, activities, and so on. Nevertheless, there aresome things that need to be improved, especially in the supervision and evaluation of the implementation of Child-Friendly City. To be able to realize a Child-Friendly City, depok city can improve the quality of monitoring and evaluation of the implementation of Child-Friendly City and bekerja same with related parties in terms of providing children's rights.

\section{References}

[1] Soerjono Soekanto. Introduction to Legal Research. Cet.3. Jakarta: Publisher, University of Indonesia, 1986.

[2] Indonesia, Regulation of the Minister of Women Empowerment and Child Protection concerning Child-Friendly Regency/City Development Policy, Permen PPPA Number 11 of 2011, State News No. 168 of 2012

[3] Magelang News. Mag Elang's ImmunizationCoverage Exceeds Target. http://beritamagelang.id/cakupan-imunisasi-kabupaten-magelang-lampaui-target, http://beritamagelang.id/cakupan-imunisasi-kabupaten-magelang-lampaui-targetme Retrieved November 15, 2020.

[4] Jogja City. Yogya City Wins Nindya Child-Friendly City Award. https://warta.jogjakota.go.id/detail/index/6271. Retrieved November 15, 2020.

[5] Ministry of Women Empowerment and Child Protection, Child-Friendly City Policy Advocacy Materials.

[6] Ministry of Women Empowerment and Child Protection. Realizing Idol 2030, Kemen PPPA Held Rakor Acceleration KLA 128 Regency / City in Surakarta City. https://www.kemenpppa.go.id/index.php/page/read/29/1913/wujudkan-idola-2030-kemen-pppaadakan-rakor-percepatan-kla-128-kabupaten-kota-di-kotasurakartahttps://www.kemenpppa.go.id/index.php/page/read/29/1913/wujudkan-idola-2030-kemenpppa-adakan-rakor-percepatan-kla-128-kabupaten-kota-di-kotasurakarta,https://www.kemenpppa.go.id/index.php/page/read/29/1913/wujudkan-idola-2030-kemenpppa-adakan-rakor-percepatan-kla-128-kabupaten-kota-di-kota-surakarta 000 Retrieved November 15, 2020.

[7] Provinsi Central Java. Magelang City Receives Child-Friendly City Award. https://jatengprov.go.id/beritadaerah/kota-magelang-terima-penghargaan-kota-layak-boy. Retrieved November 15, 2020

[8] Radar Surabaya. Surabaya Wins Child-Friendly City Award 2017. https://radarsurabaya.jawapos.com/read/2017/07/24/3101/surabaya-raih-penghargaan-utama-kotalayak-anak-2017. Retrieved November 15, 2020.

[9] Official Website of Central Java Province. Surakarta KLA Utama 2019. https://jatengprov.go.id/beritadaerah/surakarta-kla-utama-2019/., retrieved November 15, 2020.

[10] Tribun News Jogjakarta. Yogyakarta City Once Again Won The Child-Friendly City Award. https://jogja.tribunnews.com/2018/07/23/kota-yogyakarta-kembali-raih-penghargaan-kota-layakanak. Retrieved November 15, 2020.

[11] Tribun News Jogjakarta. Magelang City Can Be Re-Titled as a Worthy City Anak Year2019. https://jogja.tribunnews.com/2019/07/24/kota-magelang-dapat-predikat-kembali-sebagai-kotalayak-anak-tahun-2019. Retrieved November 15, 2020.

[12] Unicef. Building Children Friendly Cities : A Framework for Action.http://www.unicefirc.org/publications/416. 